\title{
Effects of dietary conjugated linoleic acid on some aspecific immune parameters and acute phase protein in weaned piglets ${ }^{1}$
}

\author{
C. Corino, V. Bontempo, and D. Sciannimanico \\ Department of Veterinary Sciences and Technologies for Food Safety, University of Milan, Via Celoria 10, \\ 20133 Milan, Italy. (e-mail: carlo.corino@unimi.it). Received 11 May 2001, accepted 18 October 2001.
}

\begin{abstract}
Corino, C., Bontempo V. and Sciannimanico D. 2002. Effects of dietary conjugated linoleic acid on some aspecific immune parameters, and acute phase protein in weaned piglets. Can. J. Anim. Sci. 82: 115-117. The aim of this study was to determine the influence of dietary supplementation of conjugated linoleic acid (CLA) on some immune system parameters in piglets. Forty-two weaned piglets, $12.44 \pm 1.96 \mathrm{~kg}$ liveweight, were fed diets containing $1 \%$ sunflower oil (control, C), $0.5 \%$ CLA plus $0.5 \%$ sunflower oil (T1), and 1\% CLA (T2). After 28, d serum lysozyme $\left(1.39,1.77\right.$ and $1.86 \mu \mathrm{gL}^{-1}$, respectively, for C, T1 and T2 groups; $P<0.01)$ and total serum immunoglobulin $\mathrm{G}(\mathrm{IgG})\left(1548,1930,2075 \mathrm{mg} \mathrm{dL}^{-1}\right.$, respectively, for C, T1 and T2 groups; $P<0.05$ ) were higher in piglets fed dietary CLA. No significant effect on serum $\alpha$-1-acyl glycoprotein (AGP) was observed. These results support the view that CLA favorably influences immune response.
\end{abstract}

\section{Key words: Nutrition, CLA, immune response, piglets}

\begin{abstract}
Corino, C., Bontempo V. et Sciannimanico D. 2002. Effets de l'acide linoléique conjugué sur la réponse immunitaire non spécifique chez le porcelet. Can. J. Anim. Sci. 82: 115-117. Le but de cette étude a été d'évaluer l'influence d'une supplementation en acide linoléique conjugué (ALC) sur quelque paramètre immunitaire. Quarante deux porcelets, 12,44 $\pm 1,96 \mathrm{~kg}$ PV, ont reçu trois différents régimes: group control-C 1\% d'huile de tournesol (HT), group T1 0,5\% HT et 0,5\% d'acide linoléique conjugué (ALC), group T2 1\% ALC. Après 28 j d'alimentation différenciée le lysozyme sérique (Lys) $\left(1.39,1.77\right.$ et $1.86 \mu \mathrm{g} \mathrm{mL}{ }^{-1}$, respectivement pour $\mathrm{C}$, T1 et T2, $P<0.01)$ et les Immunoglobulines sériques de la classe G (IgG) $(1548,1930$ et 2075 respectivement pour $\mathrm{C}$, T1 et T2, $P<0.05$ ) sont significativement plus élevées chez les porcelets alimentés avec les ALC. L' $\alpha-1$ acyl glycoprotéine sérique (AGP) ne montre pas des différences significatives entre traitements. En conclusion, l'ALC apparaît comme un facteur capable de stimuler la réponse immunitaire chez le porcelet.
\end{abstract}

Mots clés: Nutrition, porcelet, acide linoléique conjugué, réponse immunitaire

Conjugated linoleic acids are geometrical and positional isomers of linoleic acid in which the two double bonds are conjugated, i.e., separated by one single carbon-carbon bond only. Interest in CLA centers on their health-promoting properties, which include antioxidant, anti-obesity and anticarcinogenic activities, demonstrated in a wide range of animal models (Pariza et al. 2001). In pigs, dietary CLA can improve growth performance and meat characteristics (Dugan et al. 1997), and a recent study indicated the CLA had a favorable influence on immune competence in nursery pigs (Bassaganya-Riera et al. 2001).

Another important property of CLA is to protect nonlymphoid tissue from lymphoid events (cytokine-mediated) associated with immune stimulation. This occurs through the regulation of lipid eicosanoid mediators, and includes the prevention of down-regulation of the immune response and the prevention of the catabolic effects of immune stim-

${ }^{1}$ Presented at the 2001 ASAS Joint Annual Meeting of $A D A S, A S A S$, and PSA and the Reciprocal Meat Conference of AMSA [J. Anim. Sci. 78 (Suppl.1): 767]. ulation (Cook et al. 1993). Other favorable effects include improved feed efficiency, change in body composition and decreased incidence of conditions associated with adverse effects of the immune response e.g., allergic reactions and autoimmune disorders (Cook and Pariza 1998).

The change in diet and environment post-weaning can be an important stressor for piglets, which can result in increased disease susceptibility (Fraser et al. 1994). The aim of this study was to investigate the effects of CLA on aspecific immune parameters, the most important defense in piglets, and on acute phase protein to indirectly estimate the CLA effects on cytokine production in weaned piglets. The health-promoting effects of CLA may be interesting as a possible alternative to growth-promoting antibiotics in animal husbandry, in particular in the context of the recent banning by the European Union of the use of most antimicrobials at sub-therapeutic levels.

Abbreviations: CLA, conjugated linoleic acids; IgG, immunoglobulin G; AGP, $\alpha-1$ acyl glycoprotein 
Forty-two (Large White $\times$ Cotswold) $\times$ (Large White $\times$ Duroc) piglets, $12.44 \pm 1.96 \mathrm{~kg} \mathrm{LW}$, and $45 \mathrm{~d}$ old, were assigned to one of three dietary groups with equal proportions of males and females in each group. Basal diet consisted of corn, blown rice, soybean meal, wheat bran, fish meal, dried whey, trace mineral and vitamin premix. Diets were formulated to contain $16.1 \% \mathrm{CP}$ as fed, $0.99 \%$ lysine and $3046 \mathrm{kcal} \mathrm{kg}^{-1} \mathrm{ME}$.

The animals were allowed ad libitum access to a postweaning diet supplemented with either $1.0 \%$ sunflower oil (C), $0.5 \%$ sunflower oil plus $0.5 \%$ CLA (T1), or $1.0 \%$ CLA (T2). CLA had been synthesized from sunflower oil and consisted of 65\% CLA isomers (Conlinco, Inc., Detroit Lakes, Minnesota 56502, USA).

The ether extract and fatty acid composition of diets are reported in Table 1.

The animals used in this experiment were cared for in accordance with the guidelines established by the European Community (n. 86/609/CEE) and approved by the Italian Ministry of Health (L. n. 116/92).

The study lasted $28 \mathrm{~d}$. Blood samples were taken from all animals on days 1 and 28 of the experiment. Serum samples were analyzed for lysozyme, total IgGs and $\alpha-1$ acyl glycoprotein (AGP). Lysozyme was determined by Micrococcus lysoplate assay (Osserman and Lawlor 1966). IgG and AGP were determined by radial immunodiffusion methods (VetRID, DBA, Segrate, Italy).

The results were analyzed by ANOVA using the SPSS procedure (SPSS 7 PC+ Statistics 7.5. SPSS Inc, Chicago, IL, 1996). Data on serum parameters were analyzed using a model that included the effects of diet and sex. The effects of sex and interaction between treatment and sex were not significant and were not reported in the results. Differences between means were tested by the Student-Newman-Keuls $t$-test.

CLA supplementation had no effect on growth performance (data not shown). The concentration of serum lysozyme was higher in animals fed CLA than in piglets fed the control diet $(P<0.01)$ (Table 2). A linear trend resulted and was also significant $(P=0.03)$, although serum lysozyme of the higher CLA-supplemented group did not differ from the lower CLA-supplemented group.

Dietary CLA supplementation increased IgG levels compared to controls $(P<0.05)$ (Table 2$)$, and a significant linear effect of the dietary treatment was also found $(P=0.03)$. This latter finding is in agreement with the results of Sugano et al. (1998) who observed increased serum IgG in rats fed diets supplemented with 0.5 and $1 \%$ CLA. According to these authors, CLA regulate the production of immunoglobulins increasing the concentrations of $\operatorname{IgA}, \operatorname{IgG}$ and $\operatorname{IgM}$, and decreasing $\operatorname{IgE}$ concentration. In pigs, as in other species, IgGs are the most representative antibodies in serum, and their concentration is an index of antibody produced against antigenic stimuli not processed by T-cells (Pescovitz 1998).

Lysozyme is particularly effective against Gram-positive microorganisms, due to its bactericidal effects and its ability to lyse bacterial cell walls. Lysozyme is non-specific first-line defense against invading microorganisms

\begin{tabular}{lccr}
\hline \multicolumn{4}{l}{ Table 1. Fat content $(\%$ as-fed) and fatty acid composition of diet } \\
\hline & \multicolumn{3}{c}{ Diet $^{\mathbf{z}}$} \\
\cline { 2 - 4 } Item & $\mathrm{C}$ & $\mathrm{T} 1$ & $\mathrm{~T} 2$ \\
\hline Fat content (\%) & 4.73 & 4.68 & 4.63 \\
$14: 0$ & 0.59 & 0.62 & 0.65 \\
$16: 0$ & 11.87 & 11.78 & 11.71 \\
$18: 0$ & 16.66 & 17.07 & 17.50 \\
$20: 0$ & 0.43 & 0.45 & 0.48 \\
$16: 1$ & 1.19 & 1.23 & 1.27 \\
$18: 1$ & 16.32 & 11.22 & 6.57 \\
$20: 1$ & 0.06 & 0.06 & 0.06 \\
$18: 2$ & 50.08 & 47.68 & 44.68 \\
$18: 3$ & 2.81 & 2.85 & 2.98 \\
& & & \\
CLA-isomers & & 3.55 & 7.13 \\
c9, t11 & $\mathrm{ND}$ & 3.49 & 7.00 \\
t10, c12 & $\mathrm{ND}^{\mathbf{y}}$ & & \\
\hline
\end{tabular}

${ }^{\mathrm{z}} \mathrm{C}$, control diet, $1 \%$ sunflower oil; T1, $0.5 \%$ CLA and $0.5 \%$ sunflower oil; T2, $1.0 \%$ CLA.

${ }^{\mathbf{N} D}$, not detected.

Table 2. Serum lysozyme, total IgG and serum AGP levels in piglets fed control diet and CLA-supplemented diets at the start of the trial (day 1) and after $28 \mathrm{~d}$ (day 28)

\begin{tabular}{|c|c|c|c|c|c|}
\hline \multirow[b]{2}{*}{ Item } & \multicolumn{3}{|c|}{ Treatment $^{\mathbf{z}}$} & \multirow[b]{2}{*}{ SEM } & \multirow[b]{2}{*}{$P$} \\
\hline & $\mathrm{C}$ & $\mathrm{T} 1$ & $\mathrm{~T} 2$ & & \\
\hline \multicolumn{6}{|c|}{ Lysozyme $\left(\mu \mathrm{g} \mathrm{mL} L^{-1}\right)$} \\
\hline Day 1 & 1.12 & 1.23 & 1.17 & 0.056 & 0.874 \\
\hline Day 28 & $1.39 a$ & $1.77 b$ & $1.86 b$ & 0.090 & 0.006 \\
\hline \multicolumn{6}{|c|}{$\operatorname{IgG}\left(\mathrm{mg} \mathrm{dL}^{-1}\right)$} \\
\hline Day 1 & 730.3 & 819.8 & 763.9 & 23.48 & 0.206 \\
\hline Day 28 & $1548.7 a$ & $1930.5 b$ & $2075.5 b$ & 105.22 & 0.018 \\
\hline \multicolumn{6}{|c|}{$\operatorname{AGP}\left(\mu \mathrm{g} \mathrm{mL}^{-1}\right)$} \\
\hline Day 1 & 876.4 & 996.9 & 978.6 & 22.67 & 0.099 \\
\hline Day 28 & 1101.3 & 1224.0 & 1282.0 & 36.84 & 0.079 \\
\hline
\end{tabular}

${ }^{\mathrm{z}} \mathrm{C}$, control diet, $1 \%$ sunflower oil; T1, $0.5 \%$ CLA and $0.5 \%$ sunflower oil; $\mathrm{T} 2,1.0 \%$ CLA. The values are means. $n=14$ for all treatments. $a, b$ Means in same row with different letters differ $(P<0.05)$.

(Depelchin 1990), while in young animals IgGs are specific but often un-amplified responses to invading antigens.

In our experiment, the serum concentrations of lysozyme and immunoglobulins were higher although not significant, in piglets fed $1 \%$ CLA supplemented diet than in $0.5 \%$ CLA diet. The lower CLA supplementation may be sufficient to influence the parameters under consideration.

Dietary CLA had no statistical effects on AGP serum levels. AGP is an acute inflammatory phase reactant mediated by interleukin-1, interleukin- 6 and tumor necrosis factor $\alpha$ (Eckersall et al. 1996). We propose that the lack of effect of CLA supplementation on AGP, in the presence of enhanced lysozyme and $\operatorname{IgG}$ levels, may be attributable to the lowered $\mathrm{PGE}_{2}$ production reported in CLA-supplemented animals (Li and Watkins 1998); this may result in reduced cytokine levels (Turek et al. 1998) and consequentially reduced stimulus of AGP release. This is also consistent with the antiinflammatory properties of CLA (Cook et al. 1993).

Bassaganya-Riera et al. (2001) recently reported nursery pigs (14 d old, $5.3 \mathrm{~kg}$ liveweight) fed CLA-supplemented 
diets $(0.67,1.33$ or $2 \%)$ had higher plasma AGP levels than non-supplemented piglets. These authors observed that the increased AGP should be interpreted in the context of other immunological parameters and that greater AGP concentrations do not indicate increased production of proinflammatory cytokines.

The different effect of CLA on AGP in our study from those reported by Bassaganya-Riera et al. (2001) may be related to management schemes and also to the differences in the age/weight of the animal or the level of CLA supplementation.

In conclusion, we have found that CLA supplementation favorably influences some immune parameters in weaned piglets, suggesting an enhancement of host defenses against invading organisms. This enhancement is likely to be particularly important in young animals that have not yet developed a more specific immune response repertoire. Our findings suggest dietary CLA should be further investigated as a possible alternative to the administration of growthpromoting antibiotics, particularly in view of the results of other studies suggesting favorable anti-inflammatory and anti-allergic effects of these isomers.

This study was supported by a grant from the Italian Ministry for Universities and Scientific and Technological Research (Cofin 2000). The authors wish to thanks Conlinco, Inc., Detroit Lakes, $\mathrm{MN}$ for providing the CLA supplement for this project.

Bassaganya-Riera, J., Hontecillas-Magarzo, R., Bregendahl, K., Wannemuehler, M. J. and Zimmerman, D. R. 2001. Effects of dietary conjugated linoleic acid in nursery pigs of dirty and clean environments on growth, empty body composition, and immune competence. J. Anim. Sci. 79: 714-721.

Cook, M. E., Miller, C. C., Park, Y. and Pariza, M. W. 1993. Immune modulation by altered nutrient metabolism: nutritional control of immune-induced growth depression. Poult. Sci. 72: 1301-1305.
Cook, M. E. and Pariza, M. W. 1998. The role of conjugated linoleic acid (CLA) in health. Int. Dairy J. 8: 459-462.

Depelchin A.1990. Immunité non spécifique. Pages 13-31 in P. P. Pastoret, A. Govaerts, and H. Bazin, eds. Immunologie animale. Médecine-Sciences Flammarion, Paris, France.

Dugan, M. E. R., Aalhus, J. L., Schaefer, A. L. and Kramer, J. K. G. 1997. The effect of conjugated linoleic acid on fat to lean repartitioning and feed conversion in pig. Can. J. Anim. Sci. 77: 723-725

Eckersall, P. D., Saini, P. K. and McComb, C. 1996. The acute phase response of acid soluble glycoprotein, $\alpha$-1-acid glycoprotein, ceruloplasmin, haptoglobin and C-reactive protein, in the pig. Vet. Immunol. Immunopathol. 51: 377-385.

Fraser, D., Feddes, J. J. R. and Pajor, E. A. 1994. The relationship between creep feeding behavior of piglets and adaptation to weaning: effect of diet quality. Can. J. Anim. Sci. 74: 1-6.

Li, Y. and Watkins, A. B. 1998. Conjugated linoleic acids alter bone fatty acid composition and reduce ex vivo Prostaglandin E2 biosynthesis in rats fed n-6 or n-3 fatty acid. Lipids 33: 417-425.

Osserman, E. F. and Lawlor, D. P. 1966. Serum and urinary lysozyme (muramidase) in monocytic and monomyelocytic leukemia. J. Exp. Med. 124: 921-952.

Pariza, M. W., Park, Y. and Cook, M. E. 2001. The biologically active isomers of conjugated linoleic acid. Prog. Lipid Res. 40: 283-298.

Pescovitz, M. D. 1998. Immunology of the pig. Pages 373-419 in P. P. Pastoret, P. Griebel, H. Bazin, and A. Govaerts, eds. Handbook of vertebrate immunology. Academic Press Inc., London, UK.

Sugano, M., Tsujita, A., Yamasaki, M., Yamada, K., Ikeda, I. and Kritchevsky, D. 1997. Lymphatic recovery, tissue distribution, and metabolic effects of conjugated linoleic acid in rats. J. Nutr. Biochem. 8: 38-43.

Turek, J. J., Li, Y., Schoenlein, I. A., Allen, K. G. D. and Watkins, B. A. 1998. Modulation of macrophage cytokine production by conjugated linoleic acids is influenced by the dietary n6-n-3 fatty acid ratio. J. Nutr. Biochem. 9. 258-266. 


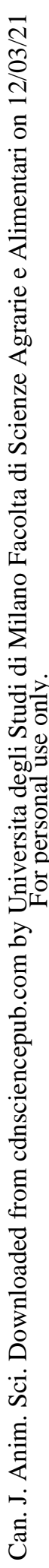

